\title{
1. Treading paths of violence: displacements of bereft Armenian children in the aftermath of genocide Anouche Kunth
}

In December 1921, Siranouch Boyadjian, a 19-year-old Armenian woman, tried for the second time to leave France in order to meet her fiancé in the United States (INS, RG $85,55175 / 561)$. Two months earlier, the Board of Special Inquiry had already refused her entry as "a person unable to read", and a second attempt did not result in a happier outcome. Her illiteracy was clearly a factor militating against her admission into the United States, as the Board's inspectors established while interrogating her about her previous education: had she ever attended school? Answering that question led Siranouch to recount memories of her childhood - "prior to my exile". The Ottoman Empire had not yet been swept away by the upheaval of World War I, but already Armenians from her native region experienced such insecurity that her parents, fearing her abduction by a neighboring Muslim family, resolved to keep their daughter home, to the detriment of Siranouch's education. Later on, the onset of systematic persecutions against the Armenian community in 1915 deprived Siranouch of her father ("I do not know what has become of him"); together with her mother, she was forcefully marched to Mesopotamia where she arrived an orphan. "We were taken from place to place", said Siranouch, describing the harrowing experience of the death march. She was finally taken by British troops who sent her to a refugee camp in Port Said, Egypt.

The following pages delve into displacement as both an instrument and a consequence of extreme violence committed against Armenian children during World War I. The war had a long-term impact on the lives of innumerable individuals (Audoin-Rouzeau, 2013), but for children the experience was particularly traumatic as they passed through the ordeal during their formative years and had to cope from an early age with loss and death. The fate of Armenian children who survived the 1915-1916 genocide has unique characteristics, as illustrated by Siranouch Boyadjian's story. Her case demonstrates a two-phase process - initial separation followed by a series of traumatizing incidents. First, the child was torn away from the security and support of a loving family; second, he or she was exposed to multiple hardships, deportation leading to refugee camps or fostering institutions, and subsequently a fate of wandering along the circuitous highways of postwar international migration in search of a stable haven. In this process, Siranouch, like so many others who had experienced war during their childhood, reached adolescence and the legal age for marrying and working.

The remarkable diversity of Armenian children's itineraries, during and after the genocide, defies any attempt to build a straightforward typology. The term "migration" itself does not do justice to the sheer ruthlessness of the series of forced displacements, abductions, escapes and other experiences to which these children were subjected. It only partly covers the movements imposed on children such as Siranouch Boyadjian just 
after the war: transfers towards secured zones, professional placements, and protracted quests for lost relatives or future spouses. This set of displacements unfurls against a background of adolescents coming of age, a period characterized by emotional turmoil even in normal, settled circumstances. One word - orphan - provides a narrative thread linking these children's different trajectories. It is a term which, once superimposed as a label upon a child's life, can never be discarded.

The migratory experiences addressed in the following pages concern such bereft children. Orphaned through a genocidal policy, they later benefitted from the intervention of various political and institutional actors who endeavored to provide for them through specially founded charitable institutions. To follow their steps is to realize their constant dilemma between a longing for a lost motherland and an aspiration to seize opportunities throughout the world. This paradoxical and double aspiration makes it difficult for historians to measure the extent of autonomous agency exercised by these young men and women as they built a life for themselves in the wake of the momentous events they had experienced.

The following investigation will lean mainly on archival, partly unpublished, material in order to highlight some of the most significant driving forces behind the migration of orphaned Armenian child: the quest for lost relatives; the rescue by charitable organizations, both public and private; and the professional placements organized by host countries. The selected examples concern Switzerland and France, countries where many private and institutional actors were involved in programs and policies on behalf of the children. Before addressing this material however, the chapter portrays, albeit through broad strokes, the violence visited upon the families, a violence which resulted in the scattering of Armenian children along the roads of exile.

\section{THE DESTRUCTION OF THE FAMILY UNIT}

In 1919 Aram Andonian published a vivid and intimate record of his ordeal. Arrested at home in pajamas on the night of April 23-24, 1915, he was thrown into the main prison of Constantinople along with hundreds of similarly rounded up Armenian notables, and later deported to remote Anatolian locations to be slowly murdered. His account echoes the dread of his companions. These men of high social standing, some of them even members of the Ottoman Parliament, had suddenly been robbed of their status and denied their internal hierarchy, leveled by a shared plight: the fear of never again seeing wives and children unexpectedly and forcibly left behind (Andonian, 1919 [2013], 76, 79-80).

Little attention has been paid to these accounts of personal anguish. The April 1915 raid against Armenian leaders has usually been analyzed for its impact, both real and symbolic, on the whole community, soon to be deported as well. But the personal narratives remind us that the patriarchal family, as a basic building-block of Armenian life, was the main sphere through which the Ottoman government implemented its plan to exterminate the Armenian population in its Empire during World War I. Men, the linchpin of this social structure, were slaughtered first; later, specific policies, described below, targeted others including various categories of children. Historical accounts focusing on familial trajectories, both during the phases of deportation and in the aftermath of the genocide, 
remain rare. Collecting material that sheds light on specific individuals, both from Turkish archives as well as from the other host countries through which Armenians were dispersed, is a painstakingly long endeavor. As a result, micro-analytic perspectives on the impact of the Armenian genocide have been limited. This chapter, by focusing on the question of orphan migration, opens up questions relating to the broader issue of Armenian family destruction, and, closely related to that, the radical break-up of kinship ties.

\section{Deportation and Child Stealing}

The wholesale deportation of the Armenian people was ordered soon after the events of April 1915, with the "Temporary Law of Deportation" (May 27) as its legal basis. The policy initially targeted the Eastern provinces, but was later implemented all over the Empire (Akçam, 2006; Dadrian, 2003a; Kévorkian, 2006). Despite its supposed temporary nature, the deportation, grimly described as methodically "pouring a people into the desert" (Dündar, 2011), had been, from the beginning, conceived as a one-way trip, a full-fledged device for dismantling and eliminating the targeted group. The deportees, mostly women, children and elderly people, forced to march to and through the Mesopotamian deserts, were harassed by Muslim bands, mostly Kurdish, who were given a license to kill, loot and rape (Davis, 1989; Toynbee, 1916). Many of the deportees were massacred by the so-called Special Organization - an entity consisting of governmental militias charged with this task. As part of the genocidal strategy, children who were not physically eliminated were targeted by policies aiming at their cultural assimilation into the Muslim community (Dadrian, 2003b). They were subjected to kidnapping and, in accordance with decrees promulgated by the Interior Minister, forcibly integrated into Turkish households, Arabic or Kurdish tribes, or Turkish orphanages hastily opened by the government in the main cities of Anatolia (Üngör, 2012, 176-178). As a result, surviving children were deprived of their identity: name, national language, religion and cultural memory.

For the Young Turks, the abduction of tens of thousands of Armenian children was an instrument of "demographic engineering" used to strengthen their group in various ways (Üngör, 2011). Held in public orphanages, children younger than ten experienced a rough education, rife with corporal punishments, aiming at providing the country with a new "Turkish" generation, whose past life's memory would have been expurgated. Held in Muslim tribes or families, Armenian children were at the mercy and discretion of their masters. While these children were sometimes treated well by decent people, they were rarely surrounded with care, and many of them were subjected to forced labor and sexual abuse. Some were even sold as chattel, with the sale hastily transacted between two individuals, or conducted in ad hoc marketplaces set up, for example, in a school where deported children were gathered after having been selected and taken out of the deportation convoys (Rhétoré, 2005). ${ }^{1}$

According to local custom, captives - either children or women - could be tattooed on their face, hands or wrists: later, during their migration, these physical scars would be mentioned on identity papers under the heading "distinguishing marks". They were seen by the survivors themselves as a concrete manifestation of their social stigma. For example, an 18-year-old girl attempting to rejoin her father in the United States in 1930 had some disturbing scars from erased tattoos near her lips - scars which were duly noted 
on the administrative record by the official of the French Prefecture where she applied for a passport (ADBR, 4 M 1125, August 1930).

It seems significant that Armenian survivors often use the term "exile" for the deportation period, which included this brainwashing endeavor to imprint on them a forced identity, a process which actually "exiled" them from themselves. Behind "exile" stood grimmer realities: death marches, captivity, servitude, the painful erasure of one's cultural and familial legacy. The term "exile", however, draws a veil of decency over the violent reality of the physical and psychological crimes endured, while at the same time highlighting the irreversible process that hurriedly brought to a close two thousand years of Armenian presence in Asia Minor. The term also draws attention to the radical rupture in life trajectory that the children experienced, even when they remained in their own native lands or within the limits of the Ottoman Empire.

\section{Escaping and Tracing Relatives}

Once the war was over, more than a thousand Armenians, still children at the time of the deportation and often growing up in detention, were able to find a haven in Aleppo. In one case a 14 year old, Hagop, managed to reach this rescue home on his own: "Hagop heard that some of his relatives were alive in Aleppo. Of course, he wanted to see them, so he fled to Urfa and from there to Aleppo" (LON, C 1601, order 60, Hagop Tashdjian). The administration of this institution recorded for each one of them as much biographical information as possible. These files, now kept in the Archives of the League of Nations, offer invaluable data on the dismemberment of Armenian family units and the circumstances that allowed the children to survive through the great upheaval following the Ottoman defeat or even, as in Hagop's case, to muster enough strength and force of will to run away and cross a war-torn zone.

Narratives of flight and evasion constitute a recurring motif in orphans' declarations, as well as in autobiographical tales. They usually emphasize a turning point leading to the decision to escape. The moment is often the one in which they first heard of a safe place dedicated to unaccompanied Armenian children. Equally overwhelming feelings of freedom and fear mingled in the children's mind as they fled, together with the painful awareness - maybe actually a retroactive, mental construct - that each step forward widened the gap between them and their former existence. Fleeing at dawn, the orphan Papken Indjarabian glanced for one last time at the hills where he used to work as a shepherd for a Kurdish master, realizing that this secluded place had ultimately been his only stable reference point in a crumbling word (Indjrabian, 2015, 100).

It would be wrong, however, to suggest that orphans' individual survival skills solely dictated the outcome of their search for freedom and safety. In the aftermath of the war, many social and institutional actors were involved in the task of tracing the deportees. It is well known that Armenians roamed the former Ottoman lands in search of children, sometimes redeeming a child in exchange for payment of a gold coin. Some survivors tried to pay ransoms to free women who had been forcibly married off or held as servants or members of harems. The scope of these community actions, supported by two powerful Armenian organizations based in Egypt, the Armenian General Benevolent Union $(\mathrm{AGBU})^{2}$ and the Human Society for the Armenian Orphans (Vorpakhenam, in Armenian), was amplified by Western charitable organizations such as the American 
Near East Relief (NER) and the British Armenian (Lord Mayor's) Fund. Both these entities had been founded as early as 1915 in response to the massacres occurring in Ottoman provinces. Another actor of prime importance was the Danish missionary Karen Jeppe, who wandered across Syrian Mesopotamia under the aegis of the League of Nations, locating women and children with the help of her agents and rescuing them with the assistance of the French military. The French military aided her efforts as France had received a mandate over the Syrian territories from the League of Nations. Young Hagop presumably passed through Jeppe's rescue-home. ${ }^{3}$ Further east, in the Mosul area, British troops similarly provided assistance to the Armenians. But wherever the Turkish nationalist forces, under the command of Mustafa Kemal, succeeded in repelling the Allied armies and driving out the undesirable minorities, the searches for separated children (and women) were called off (Çetin, 2008).

\section{Reunions around the World}

The blows inflicted to the family unit during the Armenian genocide led to brutal separations, not always corrected by the arduous efforts at tracing relatives that ensued. "Wanted notices" blossomed worldwide in the diasporic press, revealing how little individuals knew about the fate of even their closest relatives (Ter Minassian, 1997, 31). Administrative records complement these notices, illustrating how individual trips aiming at mending broken family ties blended into major, macro-level flows of international migration. Even though no centralized service, such as the post-World War II International Tracing Service, existed at the time (Zahra, 2011), passport applications provide some evidence of family tracing efforts, by demonstrating how an orphan could be reunited overseas with his remaining family members, once he or she had successfully located a relative.

Parents had to make a formal request through a notarized affidavit authenticating the parental links between themselves and their long-separated child. Hripsimé Apissoghomian was no longer a child but a 19-year-old young woman when her father declared in 1931 his desire "to bring my said daughter" to New York, where he had run a "meat-market" with his wife since 1928. He stated his will "in accordance with the resolution of the United States Congress regarding the immigration of ascertained relatives and including the minor children of aliens lawfully admitted to permanent residence in the United States" (ADBR, 4 M 1126, January 1931). In his declaration in support of reunification, the father swears he earns enough to provide for his daughter's daily needs and thus avoid her becoming a burden on the host country's welfare system. Chake Bodossian (ADBR, 4 M 1118, July 1926), aged 16 when she moved overseas from Marseilles, learned that her mother was still alive and waiting for her in Cuba, so petitioned the French Prefecture for permission to travel. Eventually, the reunion took place in 1926, after a long separation of at least seven years, during which time Chake lived in an orphanage for girls, the "Tebrotzassere", moving along with this institution through its peregrinations from Constantinople to Salonica in 1922, and then from Salonica to Marseilles in 1924. Chake's long sea voyage to the Caribbean was made under the moral patronage of the same institution.

Along with the "compatriotic" associations, ${ }^{4}$ orphanages played a key role in both mending the ties between members of scattered families and providing a measure of security for children about to engage in a new phase of migration for the purpose of 
family reunification. Thousands of children remained without any family other than the orphanage itself, a form of hospitality that could not last indefinitely. The next section investigates how young girls and boys left the Middle East and the Balkans for the West, through institutional arrangements that aimed to provide safety, education and general welfare to unaccompanied and separated children.

\section{TRANSFERS OF ORPHANS FOR EDUCATIONAL PURPOSES}

Immediately after the war, the magnitude of the Ottoman dispersal of Armenians was such that alarming reports about the distress of survivors and refugees reached the International Red Cross in Geneva. These reports came from as far afield as the South Caucasus, Cilicia, Aleppo, Constantinople or wherever Armenian Sections of the relevant local humanitarian organizations were confronted with crowds of parentless children (ACICR, B CR 00/75-245, especially articles 22, 25, 58). Violent events, which, depending on the context, took the form of deportation, massacres or sovietization campaigns, left them utterly destitute. In Caucasian Armenia, for instance, like in other regions of the Russian Empire torn apart by the Bolshevik revolution, groups of errant children (called bezprizornyie in Russian) wandered throughout the country. They were ubiquitous: on the streets and roads, starving, begging, stealing (Vita-Finzi 1975 [2000], 51-56). Sharing a border with the bloody Ottoman provinces, Caucasian Armenia also received more than 300,000 refugees from the south, significantly increasing its total population to 1.4 million. Abundant data - testimonies, reports, photographs - describe the wild behavior of rootless children and the terrible agonies of those who lay on the ground like a "pile of rags" (ILO, R 318/1, 1921-1922). ${ }^{5}$ Far from Yerevan and its scenes of urban destitution, the Armenian refugees that Pastor Krafft-Bonnard visited in Greek camps faced the great scourge of tuberculosis (Krafft-Bonnard, 1928a), while in Cilicia malaria thinned the ranks of the weak survivors (ACICR, B MIS. 19, carton 11).

Beyond the specific case of the Armenians, the human disaster constituted by displaced children deprived of all family support by the turmoil of World War I finally led to institutional arrangements, in absence of real legislative responses.

\section{Tentative Legal and Institutional Answers}

From the turn of the nineteenth century onwards, as European reformists discussed social rights and formulated demands for the protection of foreign families bound to become permanent residents on their soil, specific concerns were expressed regarding the fate of children. Western Europe laid the foundations of child welfare through the adoption of national laws on education, health and work, which primarily protected nationals. Reformist proponents of more abstract "people's rights" agitated for an extension to foreign children of these legislative bulwarks against child abuse and destitution (Droux, 2012).

These attempts to structure a legal system of child protection were buried during World War I, though the conflict did give rise to various non-governmental structures devoted to the protection of children in danger, including those who had become displaced or stateless as a result of the redrawing of international boundaries. The "Save the Children International Union" (SCIU), created in Geneva in 1920, was the first organization born 
from the awareness that the war had left innumerable child victims without any State protection after the fall of the multi-national Empires. These victims of the war were totally dependent on international charity (Droux, 2012, 6-7). The League of Nations was indebted to the SCIU for the first Declaration of the Rights of the Child adopted by the Assembly in 1924, an important international development even though, as a mere statement of commitment to the support of children's rights, it created no binding legal obligation. Similarly, the "International Association for Childhood Protection", founded in Brussels in 1921, both as a rival and a supplement to the SCIU, led to the constitution in 1925 of a special Committee for Childhood Protection within the League. Ultimately none of the Committee's projects for foreign children, based on the notion of the "best interests of the child", led to concrete results, but these early efforts had sown seeds that would bloom after World War II. ${ }^{6}$ From the onset, the debate surrounding child protection highlighted legal issues in the sphere of family law that only a consensus among members of the League could have solved; but the interwar period saw the States ever more reluctant to make any concessions in matters of national sovereignty.

What was the framework for the provision of adequate care to unaccompanied foreign children, deprived of citizenship and consequently consular tutelage, like the tens of thousands of Armenian orphans scattered all around the former Ottoman territories? ${ }^{7}$ Both Armenian and Western humanitarian foundations shared educational responsibilities for rescued children with religious missions, Catholic or Protestant. The children in question were those who despite not having traced a living relative were not considered available for adoption by their "compatriots", fellow nationals from the same home locality (Tachjian, 2007a, 61). The Near East was dotted with privately funded orphanages, which hosted up to a thousand children each. These institutions were supposed to play an important role in the national revival (Tachjian, 2007a, 67), as Armenian leaders were anxious to insure the "re-Armenization" of the children, even of those who had benefitted from Western structures like the NER. Educational programs for the younger children included gymnastic classes to fortify weakened bodies and other activities copied from the recently founded Boy Scouts movement. Older children, on the other hand, received a technical training intended to bolster their emancipation.

Orphanages were supposed to pave the way for the national reconstruction that, according to the Peace Treaty of Sèvres (1920), should have led to the establishment of an independent Armenian State. These children's homes therefore offer a useful perspective on yet another stage in the process of Armenian dispersal, because they were targeted for widespread violence by the Kemalist troops opposing Armenian independence and reconstruction.

\section{Shelters on the Move}

Perennially under threat, the orphanages followed in the footsteps of the retreating Allied armies, as they were confronted by offensive Kemalist troops. Whole shelters, including all the resident children and staff, had to be evacuated both in the heart of Anatolia, as well as Cilicia under French occupation until October 1921, and in Constantinople, where Kemal had triumphed by the autumn 1922. The hasty evacuations and ensuing retreats were sometimes preceded by arsonist attacks against orphanage buildings and by gunfire intended not only to terrorize but also to kill children. 
Manoug Semerdjian's autobiography recounts how his group had to leave the NER shelter of Aïntab in Cilicia at night, surrounded by French soldiers. They went into hiding in cave hermitages before climbing onto trucks to reach a large refugee camp near Aleppo. After passing through and camping in tents in Beirut, the exhausting journey came to its end in the city of Jbeil (ancient Byblos) where an abandoned factory was rebuilt and enlarged with the orphans' help. Even though the children were not left to their own devices, they still had to brave various dangers and cover long distances, up to 1000 kilometers (620 miles), walking or, in the best cases, riding on donkeys, before reaching Syria under French mandate (Tachjian, 2007b, 82-83).

Apart from the mandate territories, the Sultanate of Egypt and Cyprus, both under British influence, were the main havens for orphans in search of security. Due to reasons of proximity, institutions from Western Asia Minor retreated to Greece and, to a lesser measure, to Bulgaria. The major trend was to remain as close as possible to the region of origin. In these countries neighboring Turkey, demographical issues combined with economic difficulties and political tensions precluded any durable settlement for the children. The year 1923 stands as a watershed as it sealed Kemal's dominance over Turkey and accelerated ethnic homogenization of the new state: Armenian refugees - adults and children - were definitively forbidden from returning to their homeland, which became an integral part of the newly proclaimed Republic of Turkey. Under unsustainable pressure, supervisors of orphanages resolved to displace their residents further afield, now choosing Western Europe as their next destination.

France after World War I was a prime destination for refugees seeking asylum, as the Immigration Acts of 1921 and 1924 drastically reduced the opportunities to enter the United States. Migratory flows converged at the port of Marseilles on the Mediterranean Sea, with 70,000 Russian emigrants and as many Armenians disembarking on its long wharfs in the 1920s. Among these anonymous migrations, many children's trajectories can be identified by sifting through the documentation left by the bureaucratic process (AMAE, 1QO/96). Correspondence with the French Ministry of Foreign Affairs, together with the documentary proof included in collective passports with names, birthplaces and identity photographs, provides evidence of the official admission of a group of a hundred orphans onto French territory, an admission that was justified by the difficulties that this group had encountered while crossing Greece, Syria or Italy. This material sheds light on the figures soon to be scattered in France or abroad, as well as on the institutions that sponsored the immigration. For instance, the Armenian Catholic Patriarchate, whose female wards had left Smyrna after the Greek-Turkish war of 1922, and had then been hosted in Turin until 1932, waited for their transfer to France, their applications for admission supported by the Archbishopric of Paris. A French Franciscan mission in Syria played a similarly supportive role in 1925 , determined to transfer a dozen girls to a monastery located in the Jura mountains: aged 15 to 17, described as "clever, serious and prematurely matured by misfortune", they would complete their education in France and thereafter freely choose a profession. The documents also show that the Superior stressed that tattooed girls, "hideously disfigured", would not be selected to settle in France. One more example concerns 104 girls, still underage in 1925 when the Armenian (Lord Mayor's) Fund, based in London, was allowed to bring them from the Greek island of Corfu to Marseilles (AMAE, 1QO/96).

Most children perceived their collective migration to France, and more generally to 
Western Europe, as a chance to escape misery and chaos, or even as a renaissance. As discussed below, those who came specifically for work but whose age excluded them from any educational program were greatly disenchanted. Before examining the specificity of labor migration, the educational commitment of the Swiss Pastor Antony Krafft-Bonnard will be briefly presented.

\section{A Residence for Armenian Orphans in Switzerland}

Krafft-Bonnard, a prominent member of the International League of Armenophiles, was a great defender of the Armenian cause, an issue that he championed through the publication of numerous pamphlets and through strenuous efforts to rescue and provide material support for Armenian refugees. His name is associated particularly with the Armenian school that he founded in the Swiss Canton of Vaud, the valley lying in between the Alps and Lake Geneva. There, in the rural commune of Begnins, he had the ambition of forming a new generation of Armenian national élites. In the booklet he devoted to his educational charity, the pastor does not specify the criteria he used for selecting the first 20 children among thousands of others massed in Greece, but this select group in Switzerland undoubtedly benefitted from the best possible environment: at the foot of the mountains, their daily schedule alternated between physical training in a healthy environment, gardening, animal husbandry, craftsmanship to enhance child manual skills, and of course academic lessons in all subject areas required for entry to a public college, or other higher education institutions, in Geneva. The students sent to Geneva were accommodated in an "Armenian residence" attached to the school. In September 1927, at the start of the school year, 104 pupils were registered in one or the other of these twin foundations in what appears to have been an ambitious joint educational structure.

At Begnins, teaching was not limited to general disciplines, but included lessons in Armenian language and civilization. These were supposed to fill the children with pride for their cultural origins and strengthen their sense of belonging, dispelling any sense of defeatism or resignation (Krafft-Bonnard, 1928b, 16-17). Nonetheless the pastor, pondering the lack of professional opportunities for his wards even before the shock of 1929's Black Thursday, envisioned a future overseas for them, "either in the Middle East or in South America", where they could become leaders of local Armenian communities (Krafft-Bonnard, 1928b, 82). Once again, migration was seen as a likely solution for these youngsters, who had been picked up from their Greek refuge at an early age to be schooled as a new élite, rather than being allowed to roam the diasporic network if returning to a free Armenian land was to prove impossible in the end. Furthermore, the worldwide network of Armenian communities, especially those from North America, contributed from the outset to the upkeep of the orphans through a system of donations, both in the aforementioned Swiss case ${ }^{8}$ and in various other places where similar initiatives were launched. It was no coincidence that one of four cows of Begnins had been named "Chicago", a token of gratitude for the generosity of the Women Armenian Society of that faraway city. Meanwhile, in France, orphan girls of the Tebrotzassere received, among various other charitable contributions, a grand piano from a private Armenian donor who also paid for the central heating (AMAE, 1QO/96). 


\section{YOUNG WORKERS IN MIGRATION}

Some significant steps in the orphans' lives were taken quite a long time after the trials of their childhood, but this period continued to loom over their existence as the consequences of the war unfurled over decades. Furthermore, the motivations of various actors who determined their fate were not always absolutely pure, and greed wormed its way into many a charitable endeavor. Some Armenian orphans, who had just reached the legal age for working in the industrial or agricultural sectors, ${ }^{9}$ were seen as a cheap workforce readily available and left the orphanages of the American NER for France on a "voluntary" basis following a professional placement contract. "The titular arrived in France in 1923 as part of a group of 350 Armenian orphans, introduced in France by the Ministry of Labour", states an identity document belonging to the former ward of the NER (FROA009, 0962).

Such a scheme was not entirely new as Ottoman and German governments had an agreement for the latter to provide Ottoman orphans with professional training during the War. The program met with varying degrees of success, though the available data do not clearly identify the ethnic profiles of the young "Ottomans" involved (Maksudyan, 2013). But after the genocide, the leaders of the scattered Armenian nation were outraged by the professional placements policy enacted by the NER, in agreement with the French government. Its wards were dispersed in the French countryside, threatening their sense of identity through isolation and thus endangering the very survival of the Armenian nation, according to community leaders who stressed that this should have been the paramount concern of anyone intervening in Armenian affairs.

Nonetheless, a circular from the French Ministry of Foreign Affairs, dated February 8,1924 , stipulated that the government should not compromise itself by taking direct responsibility of the children's professional placement (Carlier, 2004, annexe 43). Caution demanded that the Ministry entrust this duty to reliable private entities, under the supervision of the newly founded Comité de Protection des Enfants Immigrés (Committee for the Protection of Immigrant Children). The International Labour Office applied a similarly precautionary policy. The organization provided assistance through a far-reaching program of professional placements in favor of people uprooted by World War I. In the process, they muddled the water, blurring the distinction between the juridical categories of "refugee" and "employable" migrant (Kévonian, 2005). The young Armenian orphans were officially left out of the program, as a result of the outcry of the Armenian communities, but continued to be, discreetly, subjected to professional placement.

A social history of these placements remains to be carried out. Tracing written evidence remains difficult, as the scattering of the youngsters throughout the countryside all but draws a curtain on their individual lives. Two unpublished accounts, however, mirror one another and shed light on experiences that are especially problematic to document. The authors, Manoug Semerdjian and Pakpen Injarabian, had been sheltered in NER orphanages, and were about 16 or 17 years old when they left Beirut for Marseilles, where they arrived in November 1923, one week apart. Manoug emphasizes by the following words his joy at embarking for France: "she is so beautiful this ship, unbelievable for my little head that she was here to bring me to France, the country I choose to finally live free and happy" (Semerdjian, 1990). Did the orphans really know what to expect on their arrival? What had they been told about their future life in the countryside? 
They were transferred without delay from Marseille to the Gers, a rural area in Southwest France. Arriving in the regional capital, Auch, they were surprised to be introduced to a group of peasants, who had come especially from the surrounding area to make their choice among the boys and return home with a new farm laborer. Muscles were tested and teeth checked during this cattle-market-like selection. Needless to say the process awoke painful feelings (Injarabian, 1980, 247-268). Neither Papken nor Manoug were considered prized stock, but no one was left without a patron, and after a quick registration in the local Prefecture to formalize the placement, the group of orphans was finally scattered.

The newly founded Comité de Protection des Enfants immigrés was in charge of inspection tours in the villages. In May 1925 a visiting group arrived in the Gers to facilitate the appraisal of the children's placement situation. The group included the Armenian writer Berdjouhi, herself a widow of the genocide. Brief reports regarding this springtime visit stress the isolation and despondency of the orphans. One boy of marriageable age, still called a "child" by the committee, was described as "very isolated": the referees "promised him a comrade" (FROA014, 0143-0146). Another boy, described as "happy" in May 1925, committed suicide one year later (FROA014, 085-0101). So far, these snippets of information do not allow for any generalization. Nevertheless both Papken and Manoug asserted that life was not bearable alongside patrons who never even tried to engage in any conversation with the orphans. The boys had expected more from France than becoming herdsmen and being deprived of any opportunity to learn French while forgetting, once again, their mother language. Papken fled one day, as he had done so many times in Turkey; the second boy stated as understandably as he could: "Patron, me leaving, me not staying" (Semerdjian, 1990). The farmer kindly agreed to return Manoug to the Prefecture, where the young man, denied freedom of movement, received a new work assignment in a local brickyard.

\section{IN CONCLUSION}

The next steps of their professional life are beyond the scope of this brief survey of childhood experience, even if, as already noted, the genocide subverted the usual rhythm of human life and rendered being an orphan a lifelong wound. The very same fact made these children the focus of the attention of a wide array of institutional and private actors, whose interests varied, at a time when children's rights were only slowly coming to the fore of legal thinking and social preoccupations.

Because of the focus on orphans, this brief survey has not included the many cases of children born during the migration phase, in the wake of the genocide. Many of them had parents, who themselves had been orphaned very young and who had been recently married. Yet another set of circumstances emerges through the lives of families built along the migration journey leading its members away from their former homeland. These children offer the historian new insights into the trajectories of their parents as their birth certificates register the successive stopovers of families perennially on the move. For instance, the Hamzalian's first child was born in 1920 in Constantinople, the second in Athens, in 1923, while the third was born in Valence (Drôme, France) in 1923 (ADD, 6 M 573); each birth is a milestone flagging a precise historical sequence in between political 
upheavals and a further step towards relocation in the West. When Armenians reached France after the genocide, they paradoxically appeared as big families with very young children, whose presence worried the local authorities, sometimes to the point of straight rejection (ADBR, $4 \mathrm{M}$ 957). What was to be done with these foreign children? Did the Republic, that had established mandatory free secular schooling in 1882, have to provide for their education? The prefect of the Bouches-du-Rhone asked his superiors this very question at the beginning of the 1920s.

The naturalization files reveal not only that Armenian children, who were officially stateless refugees, were actually integrated into French public schools, but also that the French administration monitored their progress as a way of estimating their capacity to function as proper citizens, and therefore to constitute "assets" for France. The same criteria were used to respond to requests from orphaned youngsters still waiting for authorization to enter France. The archbishopric of Paris boasted to the Ministry of Foreign Affairs about the "excellent household education" imparted to orphaned girls by Catholic nuns in Turin in order to ensure that they would "marry advantageously to establish families perfectly amenable to French influence, if not completely French" (AMAE, 1QO/96, 1932).

\section{NOTES}

1. Such an instance of the sale of human beings is documented, for example in the archives of the League of Nations; the biography of Papken narrates the organization of a market for the same purpose.

2. The AGBU was created in 1906 by an Armenian personality from Cairo, Boghos Nubar Pacha.

3. The documentation kept in the League of Nations, pertaining to an otherwise unspecified "orphanage in Aleppo", probably comes from Karen Jeppe's relief center in Aleppo.

4. These "compatriotic unions" gathered in the host countries consisted of people native of the same geographical locality, generally a city of the Ottoman Empire (more specifically an administrative center of a vilayet, such as Van, Sivas or Erzerum) and its surrounding neighborhood. Unions had authority in particular to assist a person with certain administrative procedures, by supplying a certificate of identity. Witnesses authenticated filiation ties - two or three persons found most of the time in the former neighborhood. They had to declare that they used to know both parents of an individual intending to emigrate, get married, be naturalized and so on. See for instance FROA001, documents 0090, 0091 and 0092.

5. Aharonian's correspondence, February 1922, with quotations of a NER report on orphans in Armenia.

6. About the interwar initiatives and their future, see Chapter 2 by Heide Fehrenbach in the present volume.

7. Soviet Armenia would at first pretend to be such a "home" for the refugees banished from Turkey, but the only plan of "repatriation" conceived that Soviet Armenia had in common with the League of Nations was definitely dropped in 1929 (Kévonian, 2004).

8. In this case they worked along the Fédération des Comités suisses amis des Arméniens ("Federation of Swiss Armenian Friendship Committees").

9. The legal age was set at 14 at the very beginning of the 1920 s by the first Conventions of the International Labour Office.

\section{BIBLIOGRAPHY}

\section{Archives}

ACICR: Archives of International Committee of the Red Cross (Geneva), B MIS. 19, (Mission Sanitaire Arménienne); B CR 00/75-254 (Croix-Rouge Arménienne, 1919-1949). 
ADBR: French Departmental Archives of the Bouches-du-Rhone (Marseilles), 4 M 956-962, Réfugiés (1837-1939); 4 M 1116-1138, Passeports, visas, sauf-conduits, laissez-passer.

ADD: French Departmental Archives of the Drome (Valence), 6M 572-574, Nationalitéarménienne (1920-1941).

AMAE: Archives of the French Ministry of Foreign Affairs (La Courneuve), 1QO/96, Demandes d'entrées d'orphelins arméniens en France, 1925-1933.

FROA: French Office for the Protection of Refugees and Stateless Persons (Val-de-Fontenay, OFPRA), files of the Armenian Office (FROA001-FROA015)

ILO: International Labour Organization (Geneva), R (Refugees), R 318/1 (1921-1922), Refugees, Russian refugees, Starvation in Russia, Famine in Armenia.

INS: U.S. National Archives (Washington D.C.), Immigration and Naturalization Service. Subject and Policy files, RG 85, 55175.

LON: League of Nations (Geneva), C 1601-1603, Armenian Orphanage, Aleppo.

\section{Printed Sources}

Andonian, Aram (1919), Sur la route de l'exil, reprinted (2013) Geneva: MētisPresses.

Bulletin de l'Union Internationale de Secours aux Enfants (Geneva).

Çetin, Fethiye (2008), My Grandmother: A Memoir, London: Verso.

Davis, Leslie A. (1989), The Slaughterhouse Province: An American Diplomat's Report on the Armenian Genocide, 1915-1917, New Rochelle, NY: Caratzas.

Krafft-Bonnard, Antony (1928a), La tuberculose et la jeunesse arménienne, from Semeur Vaudois, Lausanne.

Krafft-Bonnard, Antony (1928b), École arménienne. Begnins et Genève, Lausanne.

Indjrabian, Papken (1980), La solitude des massacres, partially reprinted and translated in English by E. Eacker (2015), Azo the Slave Boy and His Road to Freedom, London: Gomidas Institute.

Panian, Karnig (2015), Goodbye, Antoura: A Memoir of the Armenian Genocide, Palo Alto, CA: Stanford University Press.

Revue internationale de l'enfant (Geneva).

Rhétoré, Jacques (2005), Les chrétiens aux bêtes. Souvenirs de la guerre sainte proclamée par les Turcs contre les chrétiens en 1915, Paris: Le Cerf.

Semerdjian, Manoug (1990), typescript autobiography, partially published in Manoug, l'Arménien sans souci. Compagnon charpentier du Tour de France, Paris: Fédération compagnonnique des métiers du bâtiment.

Toynbee, Arnold (1916), The Treatment of Armenians in the Ottoman Empire, 1915-1916. Documents presented to Viscount Grey of Fallodon, Secretary of State for Foreign Affairs. With a preface by Viscount Bryce, London: J. Causton and Sons.

Tsarukean, Antranik (1955), Mankut'iwn ch'unets'ogh martik (in Armenian), reprinted and translated in English by E. Bayizian and M. Margossian (1985), Men without Childhood, New York: Ashod Press.

Vita-Finzi, Paolo (1975), Diaro caucasico (1928-1931), reprinted and translated in French (2000), Journal caucasien (1928-1931), Paris: L'inventaire.

\section{Secondary Literature}

Adjemian, Boris (2013), La fanfare du négus. Les Arméniens en Éthiopie, XIXe-XXe siècles, Paris: Éd. de l'EHESS.

Akçam, Taner (2006), A Shameful Act: The Armenian Genocide and the Question of Turkish Responsibility, New York: Metropolitan Books.

Audoin-Rouzeau, Stéphane (2013), Quelle histoire. Un récit de filiation (1914-2014), Paris: Seuil.

Carlier, Bruno (2004), Sauvageons des villes, sauvageons aux champs. Les prises en charge des enfants délinquants et abandonnés dans la Loire (1850-1950), $\mathrm{PhD}$ thesis in History, University of Lyon 2.

Dadrian, Vahakn N. (2003a), The History of the Armenian Genocide: Ethnic Conflict from the Balkans to Anatolia to the Caucasus, 4th edn, New York: Berghahn Books.

Dadrian, Vahakn N. (2003b), "Children as Victims of Genocide: The Armenian Case", Journal of Genocide Research, 5 (3), 421-427.

Droux, J. (2012), "Migrants, apatrides, dénationalisés. Débats et projets transnationaux autour des nouvelles figures de l'enfance déplacée (1890-1940)", Revue d'histoire de l'enfance "irrégulière", 14, http://journals. openedition.org/rhei/3383\#toctoln2.

Dündar, F. (2011), "Pouring a People into the Desert: The 'Definitive Solution' of the Unionists to the Armenian Question", in Ronald G. Suny, Fatma M. Göçek and Norman M. Naimark (eds), A Question of Genocide, 1915: Armenians and Turks at the End of the Ottoman Empire, Oxford: Oxford University Press, pp. 276-284. 


\section{Research handbook on child migration}

Dupont-Bouchat, M.-S. (2003), "Le mouvement international en faveur de la protection de l'enfance (1880-1914)", Revue d'histoire de l'enfance "irrégulière”, 5, 207-235.

Kévonian, Dzovinar (2004), Réfugiés et diplomatie humanitaire. Les acteurs européens et la scène proche-orientale pendant l'entre-deux-guerres, Paris: Publications de la Sorbonne.

Kévonian, Dzovinar (2005), "Enjeux de catégorisations et migrations internationales: Le Bureau International du Travail et les réfugiés (1925-1929)”, Revue européenne des migrations internationales, 21 (3), 95-122.

Kévorkian, Raymond H. (2006), Le génocide des Arméniens, Paris: Odile Jacob.

Maksudyan, N. (2013), "Des convois de gamins. L'envoi de jeunes orphelins ottomans en Allemagne pendant la Première Guerre mondiale" (Wagons Full of Lads. Sending of Ottoman Children to Germany during the First World War), Revue d'histoire de l'enfance “irrégulière”, 15, http://journals.openedition.org/rhei/3488.

Rollet, C. (2001), "La santé et la protection de l'enfant vues à travers les congrès internationaux (1880-1920)", Annales de démographie historique, 1, 97-116.

Tachjian, Vahé (2007a), "Femmes et orphelins à l'origine de la reconstruction d'une nation: l'œuvre et ses paradoxes", in Raymond Kévorkian, Lévon Nordiguian and Vahé Tachjian (eds), Les Arméniens 1917-1939. La quête d'un refuge, Paris: Réunion des musées nationaux, pp. 57-91.

Tachjian, Vahé (2007b), "Orphelinats arméniens du Liban, de Syrie et de Palestine", in Raymond Kévorkian, Lévon Nordiguian and Vahé Tachjian (eds), Les Arméniens 1917-1939. La quête d'un refuge, Paris: Réunion des musées nationaux, pp. 82-91.

Ter Minassian, Anahide (1997), Histoires croisées. Diaspora, Arménie, Transcaucasie, 1890-1990, Toulouse: Parenthèses.

Üngör, U. Ü. (2011), “Turkey for the Turks': Demographic Engineering in Eastern Anatolia, 1914-1945”, in Ronald G. Suny, Fatma M. Göçek and Norman M. Naimark (eds), A Question of Genocide, 1915: Armenians and Turks at the End of the Ottoman Empire, Oxford: Oxford University Press, pp. 287-305.

Üngör, U. Ü. (2012), 'Orphans, Converts, and Prostitutes: Social Consequences of War and Persecution in the Ottoman Empire, 1914-1923', War in History, 19 (2), 173-92.

Zahra, Tara (2011), The Lost Children: Reconstructing Europe's Families after World War II, Cambridge, MA: Harvard University Press. 